\title{
Motor cycle spoke wheel injuries in children: A preventable accident
}

\author{
Fatima Naumeri, M.D., ${ }^{\circ}$ Bilal Qayyum, M.D., ${ }^{1} \odot$ Nadeem Ilahi Cheema, M.D., ${ }^{1}$ \\ 다 Muhammad Sohail, M.D., ${ }^{2} \odot$ Muhammad Mustehsan Bashir, M.D. ${ }^{2}$
}

${ }^{1}$ Department of Paediatric Surgery, King Edward Medical University, Lahore-Pakistan

${ }^{2}$ Department of Plastic Surgery, King Edward Medical University, Lahore-Pakistan

\begin{abstract}
BACKGROUND: The incidence of motorcycle-induced spoke wheel injury is on the rise in our set up. These injuries range from minor soft tissue laceration to extensive crush injuries. This study aimed to evaluate the mechanism, characteristics, incidence and management of wheel spoke injuries.

METHODS: Data of all children admitted to Pediatric Surgery Emergency from January 2014 to December 20I7, presenting with wheel spoke injuries were analyzed. Incidence, mechanism and characteristics of injury, along with management plan, were noted. The outcomes were assessed by evaluating patients in follow up.

RESULTS: Total study patients were 120, with an incidence of $21.7 \%$. Mean age was $8.03 \pm 2.28$ years. There were 101 male patients and nine female patients. All patients were passengers and were sitting astride. Most of the patients were wearing shoes, and hindfoot area of the right foot was mainly involved. Grade 2 injury was seen in 55 (45.8\%) and Grade 3 in 55 (45.8\%) patients. Flap was needed in $27(22.5 \%)$ patients. All patients were mobile at the time of the follow-up.
\end{abstract}

CONCLUSION: We noted the rising incidence of entrapment injuries; however, we had a satisfactory outcome in our patients using different management techniques. We recommend the implementation of safety protocols to avoid such catastrophic injuries.

Keywords: Child; entrapment; foot injuries; motorcycle; spoke injuries.

\section{INTRODUCTION}

Motorcycle injuries are one of the major causes of road traffic accidents in urban and suburban areas of developing countries like Pakistan. ${ }^{[I]}$ The incidence of motorcycle-induced spoke wheel injuries (i.e. the feet of the rider getting trapped in the rotating spokes of the wheel of a motorcycle) is increasing in our part of the world because of lack of safety protocols and children are the main victims. ${ }^{[2]}$ The spectrum of spoke wheel injury ranges from minor soft tissue laceration to extensive crush injury with tendon and bony involvement to subtotal amputations, mainly involving heel and ankle sites. ${ }^{[2-4]}$

Management of the spoke wheel injuries is often challenging and is based on the location and grade of injury. Oestern and
Tscherne classification (grade 0 to 3 ) is the most commonly used grading system to determine the extent of tissue damage. Management may involve multiple surgeries, including debridement of dead and devitalized tissues, repair of tendons, fracture fixation, skin grafting and flaps to salvage the limbs. ${ }^{[3,4]}$

Our study objective was to evaluate the mechanism, characteristics, incidence and management of wheel spoke injuries. A previous study conducted in Pakistan in 2004 showed that children predominantly presented with spoke wheel injuries due to bicycles. ${ }^{[5]}$ Our study shows the alarming trend of all children presenting after spoke wheel injuries due to the mo-

Cite this article as: Naumeri F, Qayyum B, Cheema NI, Sohail M, Bashir MM. Motor cycle spoke wheel injuries in children: A preventable accident. Ulus Travma Acil Cerrahi Derg 2019;25:474-478.

Address for correspondence: Fatima Naumeri, M.D.

House\#93, Block-P, Phase-I, Defence Housing Authority, 54000 Lahore, Pakistan

Tel: +92429921 I I 29 / 5 I I E-mail: fatimanaumeri@gmail.com

Ulus Travma Acil Cerrahi Derg 2019;25(5):474-478 DOI: 10.14744/tjtes.2019.04052 Submitted: 28.10.2018 Accepted: 23.01.2019 Online: 22.08.2019 Copyright 2019 Turkish Association of Trauma and Emergency Surgery 
torcycle. The rationale of this study was to determine the injury mechanism and thus emphasize preventive measures based on its mechanism.

\section{MATERIALS AND METHODS}

All the study protocols were approved by the Institutional Review Board. Medical records of all children presenting in Department of Pediatric Surgery, from January 2014 to December 2017, after entrapment injury to the foot due to wheel spokes, were reviewed. Children with polytrauma were excluded from this study. Informed consent was taken from parents. Demographic details (age and gender), mechanism and characteristics of injury (e.g. side of the foot, location of injury and severity of the injury, type of footwear at time of accident and relation of foot position with wheel, time from injury to presentation), laboratory data and $X$ - ray findings of patients were noted. Management plan and outcome (mobility according to age) were noted.

Treatment was administered according to the location and severity of injury based on Oestern and Tscherne classification. ${ }^{[3,4]}$

"Grade 0 little or no injury to soft tissue

Grade I Minor abrasion

Grade 2 Local damage to skin or muscle

Grade 3 Extensive damage to soft tissue and underlying structures"

Parents were counselled regarding treatment modalities and their likely complications. The treatment employed included wound debridement, dressings and splint, skin graft and flap coverage or combination. Antibiotics were prescribed depending on the severity of injury and culture reports.

In all patients, the wound was thoroughly washed and dressed in antibacterial cream. The limb was splinted with below-knee plaster of Paris slab and kept elevated. Treatment was continued for two to three weeks for Grade I injury patients till wound healed.

In patients with moderate to severe injury (Grade 2 and 3), dead and necrotic tissue was debrided under anaesthesia. The wound was inspected regularly, and if required, repeat debridement was performed.

Split thickness skin graft harvested from the thigh was applied to well-granulated wounds over non-weight- bearing areas. The graft was applied in close contact with a recipient bed with three-layered dressing. Grafted part of the limb was immobilised. The first dressing was changed on day five. Massage with steroid cream and compression garments were started after graft maturation, three to four weeks postoperatively. Patients with grade 3 injury were managed at the plastic surgery department.
After debridement in severe injury patients, VAC therapy was also used. A controlled negative pressure to wound was applied in cyclical fashion using the VAC device to remove blood or serous fluid. The application was repeated after three days and continued till wound was ready for further management. Flap coverage was performed for wounds with an exposed, fractured bone, ruptured tendons and/or weight-bearing area. Ruptured tendons were repaired using proline 4/0, and fractures were fixed by the orthopedic surgeon with the help of wires and screws. Skin defect was covered by the flap. Division and insetting of the flap were performed at three weeks interval.

Reverse Sural Flap: Under general anaesthesia, the patient was placed in a prone position, and the trajectory of the lesser saphenous vein and the sural nerve was marked by drawing a line starting from the middle of the popliteal fossa to the posterior side of the lateral malleolus. Perforators were marked with hand-held Doppler. A tourniquet was used in all cases, but the lower limb was not previously emptied of blood; the perforators and plexuses can be seen better. The cutaneous island to be transferred was drawn on the middle third of the leg. The pivot point of the pedicle was kept 5 to $7 \mathrm{~cm}$ above the lateral malleolus. The procedure was started by incision at the top of the skin island, to locate the sural nerve and lesser saphenous vein. The sural nerve and the lesser saphenous vein were ligated proximally. The dissection was carried from proximal to distal, including deep fascia and vascular pedicle preserving the lower medial and lateral perforators. The pedicle width was kept $3 \mathrm{~cm}$, and the flap was rotated 180 degrees and transposed to cover the defect without tension. Donor area was covered with a split-thickness skin graft.

Medial Plantar Flap: This sensate fascia-cutaneous flap was raised from non- weight-bearing region of same foot and based on the medial plantar vessels. Flap was raised under Tourniquet control. Axis of the flap was drawn as a line from medial calcaneum to great toe metatarsal head. Flap was incised and raised from lateral to medial until the intermuscular septum with its perforators was seen and then dissection was carried out from the other side. Abductor Hallucis retracted medially to expose the medial plantar artery and nerve and the distal end of the vessels were divided. Flap was elevated with the vessel and septum, leaving the medial plantar nerve behind and was transposed to cover the defect. The donor site was skin grafted. Patients were mobilized usually six weeks after surgery and followed for one year postoperatively.

Data were entered in SPSS 23. Mean and standard deviation of quantitative data (age) was recorded. Frequency and percentages of qualitative data (e.g. gender, the position of the foot, type of footwear, injury grade, treatment modality, and mobility) were calculated. Association of injury grade and need for flap were analyzed with age, gender, type of footwear, position and area of foot involved using logistic re- 

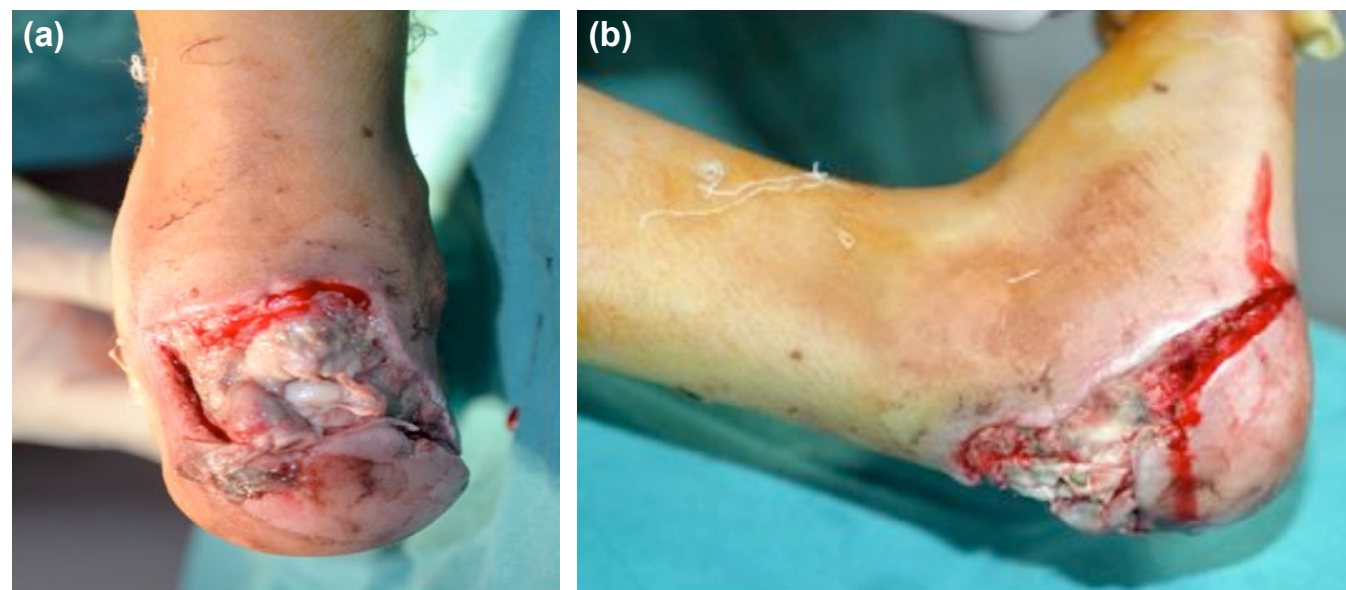

Figure 1. (a) Grade-III injury in a patient. (b) Grade-II injury in a patient with partial tendoachilles tear.

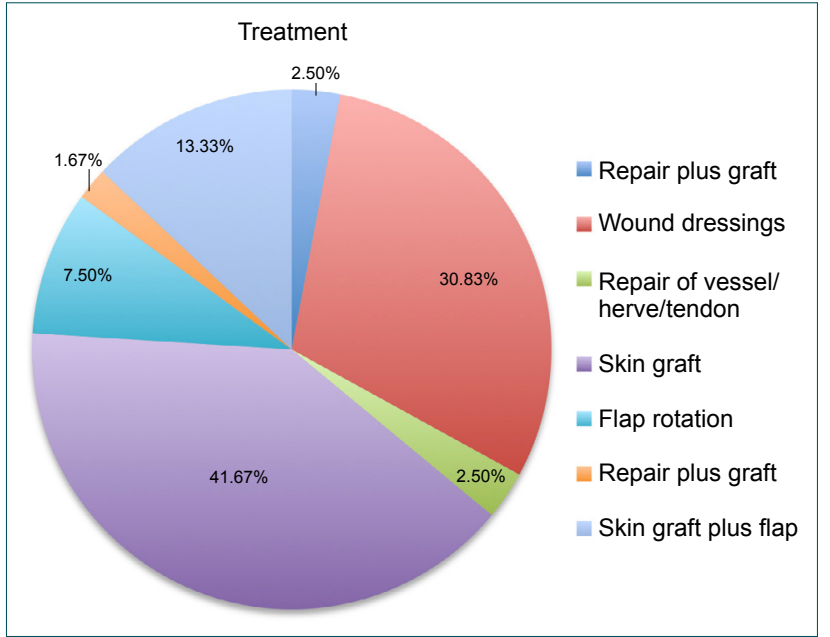

Figure 2. Different treatment modalities.

gression. The need for flap with a grade of injury was also analyzed using the Pearson chi-square test. P-value of less than 0.05 was taken as statistically significant.

\section{RESULTS}

Patients admitted to the Department of Pediatric Surgery during the study period after trauma were 553, out of which patients admitted after spoke wheel injuries were 120 (2I.7\%). Mean age was $8.03 \pm 2.28$ years. I0I (84.2\%) male and 19 (15.8\%) were female. All patients (100\%) had suffered injuries as passengers of motorcycle and were sitting astride. The foot was trapped in the front-wheel in eight (6.7\%) patients and back wheel in I I 2 (93.3\%) patients. Fiftythree (44.2\%) were wearing chappal, 63 (52.5\%) were wearing shoes and 4 (3.3\%) were wearing no footwear. The right foot was involved in 93 (77.5\%) patients, and the left foot was involved in 27 (22.5\%) patients.

Forefoot was involved in $2(1.7 \%)$ patients, midfoot in 5 (4.2\%), hindfoot in 84 (70\%), forefoot and midfoot in 4 (3.3\%) patients and hindfoot with the midfoot in 25 (20.8\%) patients. $108(90 \%)$ patients presented within a day of the injury and only $12(10 \%)$ patients presented late.

Grade I injury was seen in 10 (8.3\%) patients. Grade 2 injury was seen in 55 (45.8\%) and Grade 3 in 55 (45.8\%) patients. Figure $\mathrm{l} a$ and $\mathrm{b}$ show different grades of injuries in patients. Treatment modalities are summarized in Figure 2.

Flap was needed in 27 (22.5\%) patients. Reverse sural artery flap was done in 23 patients, while four patients underwent medial plantar artery flap. There were no complications, like flap necrosis or graft rejection. Follow up after one year confirmed that all children were mobile, though some children had difficulty in climbing stairs. Outcome after skin grafting and flap can be seen in Figure $3 a$ and $b$.
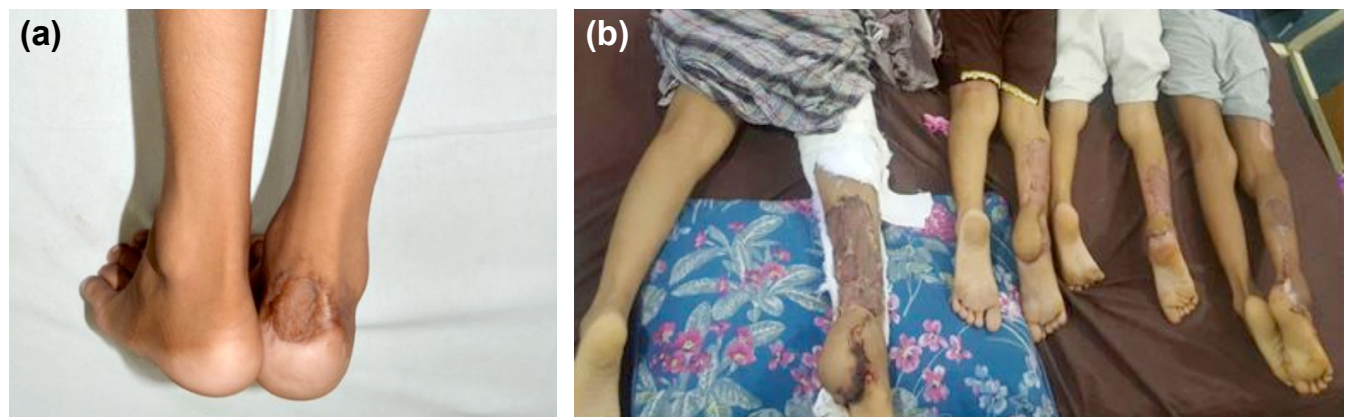

Figure 3. (a) Satisfactory outcome noted after skin grafting in patient with grade-II injury. (b) Satisfactory outcome noted after flap repair in patients with grade-III injury. 
There was no association between the need for flap and age, gender, type of footwear, position and area of foot involved. Similarly, there was no association between the grade of injury and age, gender, type of footwear, position and area of foot involved. However, we found a significant association between the need for flap and injury grade ( $p$-value $0.000 \mathrm{I}$ ).

\section{DISCUSSION}

Since first reported in 1948, spoke wheel injuries are on the rise and its reported incidence is $4.3 \%$ of all trauma patients. [6] Road traffic accidents data from Thailand alone showed that almost $70 \%$ of the morbidity and mortality in children (less than 15 years of age) was due to motorcycle injuries. ${ }^{[1]}$ In Pakistan, there has been a $400 \%$ increase in motorcycles in the last decade, and our study showed the alarming trend of children presenting after spoke wheel injuries due to a motorcycle, instead of a bicycle. ${ }^{[7]}$ Incidence was $21.7 \%$ of all trauma patients presenting in our emergency. Reason of such a high incidence in our setup is no age limitation on riding, lack of wheel guards and footrests and overloading. Traffic regulations in developed countries prohibit children younger than seven years to ride motorcycles. ${ }^{[6,8]}$

Our study showed that the right foot was more commonly involved and the area most susceptible was hindfoot, which is similar to other studies, as on left side chain guards act as a protection. ${ }^{[6,8]}$ Literature suggests that wearing shoes help in decreasing the severity and incidence of spoke wheel injuries, but in our study, footwear did not help in reducing the severity. ${ }^{[6]}$ Boys of age group 2-6 years were more commonly affected, which is consistent with other studies in the literature. ${ }^{[8,9]}$

Motorcycles cause high energy trauma, so children are unlikely to present after grade I injury. ${ }^{[6]}$ In our study, only $8.3 \%$ of children presented with grade I injury. Higher the grade, likelihood of multiple debridement increased. We noted that treatment and prognosis were directly related to a grade of injury.

Grade 2 injury has an early time of presentation. ${ }^{[6,8]}$ We admitted these patients and after initial debridement, re-evaluated all in 48 hours. No wound was primarily stitched on day of admission as vascularity is compromised. ${ }^{[4]}$ Tendons were repaired and fractures stabilized if needed. Graft was done with or without the application of VAC in cases of soft tissue injuries. In grade 3 injury, the flap was performed in the plastic surgery department. As foot does not have adequate muscle and sole needs to bear weight, we preferred local flaps as our primary choice. ${ }^{[10]}$ Choice of the flap also depended on defect size and site. ${ }^{[6,10]}$ The most common used flap was reverse sural flap which has dependable blood supply with a preserved lesser saphenous vein. ${ }^{[6,11]}$ The medial plantar flap was also performed as it is specialized glabrous skin and is perfect for the reconstruction of heel defects. Although microvascular surgery and other flaps have also been used in these injuries, we did not require these in our study. We did not have any case of flap necrosis or any other complications. In follow up, good weight-bearing was noted.

We did not calculate healing time, and although we followed up, detailed psychological or motor examination was not undertaken. A study conducted on long term follow up showed $14 \%$ had behavioural problems and mean healing time was markedly increased in grade three injuries. ${ }^{[9]}$ Implementation of safety protocols, use of protective gear, guards on the wheel can help in prevention. ${ }^{[12,13]}$

\section{Conclusion}

We noted a rising incidence of these entrapment injuries; however, we had a satisfactory outcome in our patients using different management techniques. We recommend the implementation of safety protocols to avoid such catastrophic injuries.

\section{Conflict of interest: None declared.}

\section{REFERENCES}

1. World Health Organization, Regional Office for South-East Asia. (2015). Child development and motorcycle safety. Available at: http:// www.who.int/iris/handle/10665/173782. Accessed August 2, 2019.

2. Rathinam C, Nair N, Gupta A, Joshi S, Bansal S. Self-reported motorcycle riding behaviour among school children in India. Accid Anal Prev 2007;39:334-9. [CrossRef]

3. Gupta HK, Shrestha R. Bicycle-spoke injuries of the foot and ankle: A prospective study. J Coll Med Sci-Nepal 2014;9:36-9. [CrossRef]

4. Agarwal A, Pruthi M. Bicycle-spoke injuries of the foot in children. J Orthop Surg (Hong Kong) 2010;18:338-41. [CrossRef]

5. Safdar CA. Bicycle and motorcycle spoke injuries in children as passengers. J Coll Physicians Surg Pak 2005;15:802-4.

6. Zhu YL, Li J, Ma WQ, Mei LB, Xu YQ. Motorcycle spoke injuries of the heel. Injury 2011;42:356-61. [CrossRef]

7. Hamza A. Motorcycle production in Pakistan reaches nearly $2 \mathrm{~m}$ per annum. Daily Times [newspaper on the internet]. Available from: http:// dailytimes.com.pk/93038/motorcycle-production-in-pakistan-reachesnearly-2m-per-annum/. Accessed August 2, 2019.

8. Agu TC. Motorcycle spokes entrapment foot injuries: Prevalence, and pattern of presentation in a private orthopedic and trauma centre, Southeast Nigeria-A 10-year retrospective analysis. Afr J Trauma 2017;6:6-10.

9. Sturms LM, van der Sluis CK, Snippe H, Groothoff JW, ten Duis HJ, Eisma WH. Bicycle spoke injuries in children: accident details and consequences. [Article in Dutch]. Ned Tijdschr Geneeskd 2002;146:1691-6.

10. Vlastou C. Alternatives in soft tissue reconstruction of the ankle and foot. Acta Orthop Scand Suppl 1995;264:27-30. [CrossRef]

11. Farooq HU, Ishtiaq R, Mehr S, Ayub S, Chaudhry UH, Ashraf A. Effectiveness of Reverse Sural Artery Flap in the Management of WheelSpoke Injuries of the Heel. Cureus 2017;9:e1331. [CrossRef]

12. Mak CY, Chang JH, Lui TH, Ngai WK. Bicycle and motorcycle wheel spoke injury in children. J Orthop Surg (Hong Kong) 2015;23:56-8.

13. Solagberu BA, Ofoegbu CK, Nasir AA, Ogundipe OK, Adekanye $\mathrm{AO}$, Abdur-Rahman LO. Motorcycle injuries in a developing country and the vulnerability of riders, passengers, and pedestrians. Inj Prev 2006;12:266-8. [CrossRef] 
ORİJINAL ÇALIŞMA - ÖZET

\section{Çocuklarda motosiklet ispitli tekerlek yaralanmaları: Önlenebilir bir kaza}

\section{Dr. Fatima Naumeri, ${ }^{1}$ Dr. Bilal Qayyum, ${ }^{1}$ Dr. Nadeem Ilahi Cheema, ${ }^{1}$}

Dr. Muhammad Sohail, ${ }^{2}$ Dr. Muhammad Mustehsan Bashir ${ }^{2}$

\section{${ }^{1}$ Kral Edward Tıp Üniversitesi, Çocuk Cerrahisi Anabilim Dalı, Lahore-Pakistan} ${ }^{2}$ Kral Edward Tıp Üniversitesi, Plastik Cerrahi Anabilim Dalı, Lahore-Pakistan

AMAÇ: Motosiklet kullanımııın neden olduğu ispitli tekerlek yaralanmasının görülme sıklığı artmaktadır. Bu yaralanmalar küçük yumuşak doku laserasyonundan yoğun ezilme yaralanmalarına kadar uzanır. Bu çalışmanın amacı ispitli tekerlek yaralanmalarının mekanizmasını, özelliklerini, insidansını ve tedavisini değerlendirmektir.

GEREÇ VE YÖNTEM: Çocuk cerrahisi acil servisinde Ocak 20।4-Aralık 2017 tarihleri arasında başvuran, ispitli tekerlek yaralanmaları ile başvuran tüm çocukların verileri analiz edildi. Tedavi planıyla birlikte yaralanma insidansı, mekanizması ve özellikleri kaydedildi. Takipteki hastalar değerlendirilerek sonuç değerlendirildi.

BULGULAR: Çalışmaya alınan toplam hasta sayısı I20, yaralanmanın insidansı ise \%2।.7 idi. Yaş ortalaması $8.03 \pm 2.28$ yıl idi. Yüz bir adet yaralı erkek hasta mevcuttu. Hastalar ve yolcular motosiklete ata biner gibi oturuyorlardı. Hastaların çoğu ayakkabı giyiyordu ve esasen sağ ayağın arka kısmı yaralanmışı. Elli beş (\%45.8) hastada ikinci ve 55 (\%45.8) hastada üçüncü derece yaralanma görüldü. Yirmi yedi hastada (\%22.5) flep kullanılması gerekti. Tüm hastalar ayaktan takip edildi.

TARTIŞMA: Bu tuzaklanma yaralanmalarının insidansının artıı̆ına dikkat çekmekle birlikte farklı tedavi teknikleri kullanarak hastalarımızda tatmin edici sonuçlar aldık. Bu kadar feci yaralanmaları önlemek için güvenlik protokollerinin uygulanmasını öneriyoruz.

Anahtar sözcükler: Ayak yaralanması; çocuk; ispitli tekerlek yaralanması; motosiklet; tuzaklanma.

Ulus Travma Acil Cerrahi Derg 2019;25(5):474-478 doi: 10.14744/tjtes.2019.04052 